\title{
Wrong about Rights: Public Knowledge of Key Areas of Consumer, Housing and Employment Law in England and Wales
}

Over many decades, processes of juridification have brought about huge growth in legal rights, responsibilities and protections. Yet, citizens appear to poorly understand the 'law thick' world in which they live. This impacts on the capability of citizens to 'name, blame and claim' in the legal domain; at a time of retreat from public funding of civil legal services. This paper looks at public knowledge of rights in key areas relating to consumer, housing and employment law. Drawing on data from the 2010-2012 English and Welsh Civil and Social Justice Survey, the paper uses responses to a series of hypothetical scenarios to explore public knowledge of rights and characteristics associated with knowledge. Our findings highlight a substantial deficit in the public's understanding of legal rights and responsibilities - even among those for whom particular rights and responsibilities have specific bearing. We contextualise our finding with reference to what they mean for public legal education and the efficiency, efficacy and legitimacy of the law.

Key words: legal rights, access to justice, public legal education, justiciable problems, civil justice

Word count: 7,625 (10,319 including footnotes) 


\section{INTRODUCTION}

We live in a 'law-thick' world ${ }^{1}$ in which our daily activities are played out within a complex and extensive legal framework. Successive waves of 'juridification' - defined by Habermas as "the tendency towards an increase in formal (or positive, written) law that can be observed in a modern society" - have seen law become "ubiquitous in social life" ${ }^{3}$. An increasing range of legal rights, responsibilities and protections have come to apply in the spheres of education, employment, children and families, health, housing, welfare benefits, consumer goods and services, and our environment. ${ }^{4}$

Yet, it appears that, at least in some contexts, "the vast majority of the population systematically mispredicts ... the content of the law". ${ }^{5}$ A steadily growing number of studies of the public's understanding of law point to a substantial knowledge deficit. ${ }^{6}$

\footnotetext{
${ }^{1}$ G.K. Hadfield. 'Higher Demand, Lower Supply? A Comparative Assessment of the Legal Resource Landscape for Ordinary Americans' (2010) 37 Fordham Urban Law Journal, 129-156,133.

2 J. Habermas. The Theory of Communicative Action, Volume 2: Lifeworld and System (Cambridge: Polity Press, 1987) 357. He then went on to distinguish between "the expansion of law, that is the legal regulation of new, hitherto informally regulated social matters, from the increasing density of law, that is the specialized breakdown of global statements of the legally relevant facts into more detailed statements." Habermas argued that there have been 4 epochs of juridification, with the most recent accompanying the expansion of the welfare state. Veitch et al (2007) argue that we are now in the midst of a $5^{\text {th }}$ epoch, accompanying the decline of the welfare state, comprising "the re-embedding of private law mechanisms - contract and property law in particular - within formerly public, State-owned areas" and the expansion of supranational law.

${ }^{3}$ W.Twining. Blackstone's Tower: The English Law School. (London: Sweet and Maxwell, 1994) 16

${ }^{4}$ See e,g. G. Teubner (1987) Juridification of Social Spheres: A Comparative Analysis in the Areas of Labour, Corporate, Antitrust and Social Welfare Law. Berlin: Walter de Gruyter; Howells, G. and Weatherill, S. (2005) Consumer Protection Law (2nd edn.). (Aldershot: Ashgate, 2005);T. Goriely, T.. Making the welfare state work, in The transformation of legal aid. edited by Regan, A. Paterson, T. Goriely, and D. Fleming. (Oxford: Oxford University Press, 1998); H. Gibson, H. Home-School Agreements: 'On the Rise of 'Juridification' and Contractualism in Schools'. 39 (2013) Oxford Review of Education 6, 780-796; K. Veitch,. 'Juridification, Medicalisation, and the Impact of EU Law: Patient Mobility and the Allocation of Scarce NHS Resources'. 20 (2012) Medical Law review, 3, 362-398; S. Veitch, E. Christodoulidis and L. Farmer Jurisprudence: Themes and Concepts. (Oxford: Routledge, 2012).

${ }^{5}$ Williams, n.17, 734

${ }^{6}$ See e.g. C.F. Cortese 'A Study in Knowledge and Attitudes Towards the Law' 2 (1966) Rocky Mountain Social
} 
The deficit appears greater in some areas of law than others, in part a function of salience. ${ }^{7}$ After all, there is less reason for individuals to possess knowledge with no clear bearing on their lives. So, for example, Casebourne et al.'s study of employee awareness of employment rights in the United Kingdom demonstrated that those with dependent children were "understandably" more likely than others to know a lot or fair amount about the detail of the parental right to request flexible working (40\% vs. $27 \%){ }^{8}$

There is also less reason for people to have a grasp of the intricacies of the law than broader legal principles, and again this is reflected in findings to date. ${ }^{9}$

Also, there is evidence of a lesser deficit for those with an interest in or, more predictably, relevant experience of the law. So, Baker \& Emery ${ }^{10}$ found that students just about to start a course on family law had slightly higher levels of knowledge of divorce statute law than did the general public. ${ }^{11}$ As would be expected, those who had completed the course had higher levels of knowledge still; although Baker \& Emery found that, "in absolute terms ...

Science Journal, 192-203; M. Williams, \& J. Hall. 'Knowledge of the Law in Texas: Socioeconomic and Ethnic Differences' 7(1972) Law and Society Review, 1, 99-118; LVE. Saunders, 'Collective Ignorance: Public Knowledge of Family Law’ 24(1975) The Family Coordinator, 1, 69-74; Kim n 16; J.M. Darley, C.A. Sanderson, \& P.S. LaMantia 'Community Standards for Defining Attempt: Inconsistencies with the Model Penal Code' 39(1996) American Behavioral Scientist, 4, 405-420; A. Barlow, S. Duncan, G. James, \& A. Park Cohabitation, Marriage and the Law: Social Change and Legal Reform in the 21 $1^{\text {st }}$ Century (Oxford: Hart, 2005); M. Militello, D. Schimmel, \& H. J. Eberwein, 'If They Knew, They Would Change' 93(2009) NASSP Bulletin,1, 27-52; R. Panades,, R Corney, C Ayles, J Reynolds, \& F Hovsepian Informing Unmarried Parents About their Legal Rights at Birth registration (London: One Plus One, 2007); L.J. Parle Measuring young people's legal capability (London: Independent Academic Research Studies and PLEnet, 2009); P. Pleasence, P. \& N.J. Balmer 'Ignorance in Bliss: Modeling Knowledge of Rights in Marriage and Cohabitation' 46 (2012) Law and Society Review, 2,.297-333; C. Denvir, N.J. Balmer, and P. Pleasence 'When legal rights are not a reality: do individuals know their rights and how can we tell?' 35 (2013) Journal of Social Welfare and Family Law, 1, 139-160; Baker, A. Lynn. \& R. E. Emery 'When Every Relationship is Above Average - Perceptions and Expectations of Divorce at the Time of Marriage' 17 (1993) Law and Human Behavior, 4, 439-450

${ }^{7}$ See e.g. Saunders, n.6; J. Casebourne, J. Regan, F. Neathey. \& S. Tuohy Employment Rights at Work: A Survey of Employees 2005 (London: Department of Trade and Industry, 2006); Pleasence \& Balmer n. 6

${ }^{8}$ Casebourne et al, n. 7

${ }^{9}$ Ibid

${ }^{10}$ Baker and Emory, n. 6

${ }^{11}$ Answering $64 \%$ of questions correctly, as compared to $60 \%$. 
even these students' perceptions were highly inaccurate". ${ }^{12,13}$

Beyond the substance of the law, Williams's ${ }^{14}$ review of research into litigants in person found "most research" to suggest that litigants in person experience a variety of knowledge related disadvantages; having trouble "identifying facts relevant to the case", "understanding evidential requirements" and "understanding the nature of proceedings."

All this is of concern, as poor understanding of law and process may prevent people from acting to protect their rights (or discharge responsibilities), ${ }^{15}$ prevent people acting to protect against the likelihood of particular eventualities ${ }^{16,17}$ and militate against good outcomes ${ }^{18}$. Williams's review also points to the poor knowledge of litigants in person creating "extra burden ... for court staff and judges."

Evidently, how people understand the world impacts on behaviour. For example, Felstiner, Abel and Sarat's influential framework for understanding the emergence and transformation of disputes sets out how "injurious experiences" only become transformed into disputes through being recognised ("naming"), attributed to another ("blaming"), and communicated to that other along with a request "for some remedy" ("claiming") that is

\footnotetext{
12 Ibid at 445

13 Their scores averaged $70 \%$.

${ }^{14}$ Williams, K. Litigants in Person: A Literature Review, (London: Ministry of Justice, 2011) 5

${ }^{15}$ See e.g. P. Bowal, (1999) 'A Study Of Lay Knowledge Of Law In Canada' 9 (1999) Indiana International And
} Comparative Law Review, 1, 121-141; P. Pleasence, \& N. J. Balmer, How People Resolve 'Legal' Problems (London: Legal Services Board, 2014).

${ }^{16}$ P.T. Kim, Pauline T. Norms 'Learning, and Law: Exploring the Influences on Workers' Legal Knowledge' (1999) University of Illinois Law Review, 447-515.; N. Meager, Awareness, Knowledge and Exercise of Individual Employment Rights (London: Department of Trade and Industry, 2002).

${ }^{17}$ For example, in the context of the 'common law marriage myth', which involves the systematic over-estimation of the rights of cohabitees against one another, whereas divorce acts as a "redistributive" process, "financial division on the breakdown from cohabitation sustains the financial power dynamics in the relationship" (J. Lewis, R. Tennant, \& J. Taylor. 'Financial Arrangements on the Breakdown of Cohabitation: Influences and Disadvantage' In J. Miles \& R. Probert, eds., Sharing Lives, Dividing Assets: An Inter-Disciplinary Study (Oxford: Hart, 2009) 179. Thus, poor legal knowledge will lead to some financially vulnerable cohabitants to "underinsure against the financial cost" of relationship breakdown (Hannon, W.S. 'Sticky expectations: Responses to persistent over-optimism in marriage, employment contracts and credit card use' 84 (2009) Notre Dame Law Review, 2, 759), "militate against amicable resolution of disputes" (Dowding 2009:207), and create "needless emotional harm" (Williams, p.735).

${ }^{18}$ Pleasence and Balmer, n. 15 
refused. ${ }^{19}$ Whether law is properly understood directly links to whether there is legal framing (as opposed to, say, a moral or social framing), and what form it takes, in this process of naming, blaming and claiming. And, as Pleasence, Balmer and Reimers have shown, ${ }^{20}$ legal framing is a significant influence on people's behaviour in resolving 'justiciable, ${ }^{21}$ problems; notably in relation to whether advice is sought from lawyers; who Felstiner, Abel and Sarat described as "the most important ... agents of dispute resolution ... [as a] result of the lawyer's central role as gatekeeper to legal institutions and facilitator of a wide range of personal and economic transactions". ${ }^{22}$

In the United Kingdom, both traditional legal servicesand the wider advice sector play critical roles in enabling citizens to understand the many dimensions of everyday justiciable problems, and to facilitate legal framing and action if appropriate. Thus, current concerns about poor public legal literacy are exacerbated by concerns about the retreat of public expenditure on legal services, including basic forms of legal help. For example, the net civil legal aid budget in England and Wales has fallen by $15 \%$ ( $£ 133$ million) between $2012-13$ and $2015-16,{ }^{23}$ following implementation of the Legal Aid, Sentencing and Punishment of Offenders (LASPO) Act $2012^{24}$; placing increasingly greater reliance on the abilities of individual citizens to understand and navigate the law-thick world alone. This significant challenge was recognised in the Public Bill Committee debates regarding the passage of the LASPO Bill, where it was observed that changes to legal aid demanded greater public knowledge of rights if individuals are expected to self-help and self-represent more often. ${ }^{25}$

\footnotetext{
${ }^{19}$ W.L.F. Felstiner, R.L Abel, \& A. Sarat, 'The emergence and transformation of disputes: naming, blaming, claiming ....,' 15 (1981) Law and Society Review, 635.

${ }^{20}$ P. Pleasence, N.J. Balmer, \& S. Reimers, 'What really drives advice seeking behaviour? Looking beyond the subject of legal disputes', 1 (2011) Onati Socio-Legal Series.

${ }^{21} \mathrm{~A} 15^{\text {th }}$ century word, notably defined by Genn, as a matter that raises legal issues, whether or not these are recognised as being legal and whether or not any action taken to deal with the matter involves the use of any part of the civil justice system (H. Genn, Paths to justice: What people do and think about going to law, (Oxford: Hart, 1999)).

${ }^{22}$ Felstiner, Abel \& Sarat, n.19, p.645.

${ }^{23}$ Legal Aid Agency, Annual Report and Accounts, (London: HMSO, 2014, 2016).

${ }^{24}$ Legal Aid, Sentencing and Punishment of Offenders (LASPO) Act 2012

${ }^{25}$ Public Bill Committee. 2011. Public Bill Committee Transcript of Discussions on the Legal Aid and Sentencing of Offenders Act. Available from http://services.parliament.uk/bills/2010-

11/legalaidsentencingandpunishmentofoffenders/stages.html [Accessed 28th October 2016].
} 


\section{BELIEFS ABOUT LAW, ATTITUDES AND SOCIAL NORMS}

Importantly, holding erroneous beliefs about the law is not simply a matter of chance ignorance. We have previously argued that legal reality and the public's perception of legality - both in the case of cohabitation and marriage - are each coherent and distinct, with the latter fuelled and entrenched by attitudes and social norms. As Lewis et $\mathrm{al}^{26}$ have observed, "people's perceptions of their rights and duties are learned in a social context."

In the employment context, Kim found that workers' beliefs were "systematically erroneous," yet "remarkably similar" between U.S. states, "despite wide variations in the states' laws." 27 She concluded that respondents "assumed that the requirements of the law coincide with their beliefs as to how employers should behave and, therefore, answer the legal questions according to their own notions of fairness". ${ }^{28}$

Similarly, Darley et al.'s study of people's understanding of aspects of criminal law in Wisconsin, Texas, South Dakota, and North Dakota pointed to little variation between states in citizens' beliefs about the law, despite substantial differences in the actual law. ${ }^{29}$ Drawing on the "false consensus effect" 30 they concluded that people "assume that the state, in its moral wisdom, shares their personal views". ${ }^{31}$ Even in the case of Texans' relatively good understanding of Texas's irregular law concerning the use of deadly force to protect property, differences in beliefs about the state of the law "disappeared completely when the relevant attitudes of the citizens [were] covaried out". ${ }^{32}$

Further findings from the English and Welsh Civil and Social Justice Panel Survey (CSJPS - data from which is also used for the current study) relating to a series of questions exploring a hypothetical family scenario made evident "symmetry of error in people's beliefs about marriage and cohabitation law, where beliefs about both cohabitation and marriage law err from their (often opposing) correct legal positions to rest more closely in line with social

\footnotetext{
${ }^{26}$ Lewis, et al, n. 16

${ }^{27}$ Kim, n. 16: 447 \& 45

${ }^{28}$ Ibid at 490

${ }^{29}$ J.M. Darley, K. M. Carlsmith, \& P. H. Robinson 'The Ex Ante Function of the Criminal Law' 35 (2001) Law and Society Review, 1, 165-189.

${ }^{30}$ Ross, L., Greene, D. \& House, P. (1977) 'The False Consensus Effect: An Egocentric Bias in Social Perception and Attribution Processes’ 13 Journal of Experimental Social Psychology, pp.279-301.

${ }^{31}$ Ross et al, n.30, 168

32 Ibid 178.
} 
attitudes." 33 People appeared to tend to assume the law concurred with what they thought it ought to be. For example, in the case of a childless couple who had lived together for 10 years, with the female partner having looked after the home and not worked since they started living together and the male partner having a good salary and sizeable savings, $52 \%$ of respondents wrongly believed that a financially dependent cohabitant would have had a good legal claim, with $65 \%$ believing the same in the case of a spouse, with most of the remainder wrongly believing that such a spouse would not have a claim. This reflects the attitudes of the public as indicated by the 2006 British Social Attitudes Survey more than the actual state of the law. ${ }^{34}$

\section{BELIEFS ABOUT LAW AND REFERENCE TO TIME}

Another aspect of some public beliefs about legal rights is that they are believed to crystallise over time. So, for example, research has found that survey respondent's beliefs' about the rights of spouses and cohabitees against the estate of an intestate deceased partner depended upon relationship duration. ${ }^{35}$ So, the percentage of respondents believing a cohabitee would automatically inherit went from $7 \%$ for short relationship durations to an asymptote of $27 \%$, with the increase fairly gradual as duration increased. In the case of spouses, the asymptote was $44 \%$. In both these examples (spousal relationships and cohabitees), the passing of time can be taken to be associated with the accretion of expectation and dependency on the part of cohabitees/spouses, and thus is reflected in a public expectation that the law will protect the vulnerable. The absence of such a public expectation in the case of rights linked to parenthood, such as child support and decisions about children's medical treatment, meant that beliefs were independent of relationship duration.

\section{CHALLENGES TO DISLODGING ERRONEOUS BELIEFS}

One consequence of the tendency of beliefs about the law to align with social attitudes is that, in line with cognitive dissonance theory ${ }^{36}$, erroneous beliefs may prove stubborn to dislodge.

\footnotetext{
${ }^{33}$ Pleasance and Balmer, n. 6

${ }^{34}$ Barlow et al, n.6

35 Pleasence and Balmer, n.6

${ }^{36}$ Kim, n.16; H. Mahar Why Are There So Few Prenuptial Agreements? (Cambridge, MT: John M. Olin Center for Law, Economics, and Business, 2003). Available at http://www.law.harvard.edu/programs/olin_center ; Pleasence and Balmer, n.6
} 
Cognitive dissonance theory ${ }^{37}$ predicts that when a person's cognitions (which include knowledge, opinions and beliefs) are at-odds, or dissonant, this is "psychologically uncomfortable" and will motivate the person to "reduce the dissonance and achieve consonance." Cognitive dissonance can therefore lead people to avoid or disregard "information that would likely increase the dissonance".38

For example, in the employment context, Kim argued that erroneous beliefs based on attitudes are likely to be "resistant to change", as a fairness norm "overshadows the influence of most ... experiential factors". ${ }^{39}$ Likewise, Ellickson, in his study of the law's place in ranching disputes in Shasta County, California, found that "the cattlemen resist absorbing information that is inconsistent with their folklore." 40 Thus, even repeated experience of insurance companies and courts following different principles did not dislodge belief that, in the event of road collisions in 'open range', "the motorist buys the cow."

The impact of cognitive dissonance is also compounded by common "indifference to law" resulting from phenomena such as optimism bias ${ }^{4142}$ though there is evidence that interest and objectivity may be raised during periods of life transition. For example, Gagné et al pointed to more objective thinking about the quality and risks of relationships at "choice points in the relationship or major life transitions," with greater "motivation to maintain ... positive views" once decision making has concluded. ${ }^{43}$

\section{AIMS AND HYPOTHESIS}

In this paper we build on the existing literature, using data from both waves of the English and Welsh Civil and Social Justice Panel Survey (CSJPS) to investigate more fully the profiles of those who have good and poor knowledge of their legal rights and responsibilities. We do so with a view to determining what this might say about the level of legal understanding among

\footnotetext{
${ }^{37}$ L. Festinger A Theory of Cognitive Dissonance (Stanford, CA: Stanford University Press, 1957) 3

38 Ibid,

${ }^{39}$ Kim, n. 16: 447-448

${ }^{40}$ R.C.. Ellickson Order Without Law (Harvard University Press, Cambridge, 1991) 115

${ }^{41}$ Pleasence and Balmer, n.6

${ }^{42}$ See, for example, N.D. Weinstein 'Unrealistic Optimism About Future Life Events' 39 (1980) Journal of Personality and Social Psychology, 806-820.

${ }^{43}$ F.M. Gagné, \& J.E.. Lydon 'Bias and Accuracy in Close Relationships: An Integrative Review' 8(2004) Personality and Social Psychology Review,4, 322-338: 328
} 
individuals in England and Wales, as well as to identify which groups, if any have specific education needs. While the scenarios pertain to English and Welsh law and the respondents were resident in England and Wales, findings have significance for public legal education and legal service delivery beyond this jurisdiction.

Based on Williams ${ }^{44}$ it is firstly hypothesised that individuals will answer the hypothetical questions incorrectly more often than not. Secondly, based on the work of a number of different researchers, ${ }^{45}$ it is hypothesised that in spite of a general lack of knowledge, knowledge improvements will be seen where the particular area of law is likely to be of greater salience to the individual. Given that knowledge is often acquired in a social context, it is thirdly hypothesised that household effects will be evident in our findings. That is to say that levels of knowledge will be similar by household. Finally, it is hypothesised that knowledge is likely to be higher where the legal position sits more closely in line with social norms.

\section{METHODOLOGY}

\section{Dataset}

Data in this study was drawn from the CSJPS, a large scale survey of the general population's experience of 97 types of legal problem (concerning consumer issues, employment, neighbours, owned housing, rented housing, money, debt, welfare benefits, education, clinical negligence, relationship breakdown, domestic violence and care proceedings $)^{46}$ and strategies used to resolve them. The survey was a substantial development of the English and Welsh Civil and Social Justice Survey (CSJS), which was first conducted in $2001^{47}$, then again in $2004^{48}$

\footnotetext{
${ }^{44}$ Williams n. 6

${ }^{45}$ See Saunders, n.6; Casebourne et al and Pleasence and Balmer, n.7

${ }^{46}$ Problems were identified by asking a variant of the following question in relation to each of the 13 categories of legal problem included in the surveys: "[have you/has your partner] had any (other) problems or disputes of the type shown on this card since [18 months]?"

${ }^{47}$ P. Pleasence., A.Buck, N.J. Balmer, A. O'Grady, H. Genn, \& M. Smith Causes of Action: Civil Law and Social Justice (Norwich: The Stationery Office, 2004).

${ }^{48}$ P. Pleasence Causes of Action: Civil Law and Social Justice (2 ${ }^{\text {nd }}$ Ed). (Norwich: TSO, 2006)
} 
and on a continuous basis between 2006 and 2009. ${ }^{49}$ The CSJS was itself a substantial development of the Paths to Justice survey. ${ }^{50}$

Two waves of the CSJPS were conducted prior to the survey's replacement by the Justiciable Problems Resolution Survey in 2012. Wave 1 interviews were conducted between June and October 2010. Wave 2 interviews were conducted eighteen months later, concluding in May 2012. The first wave of the survey included 3,806 respondents (aged 16+), drawn from a random selection of 2,316 residential household addresses across 194 postcode sectors of England and Wales. The household response rate was $61 \%$, and the cumulative eligible response rate was $54 \%$. The second wave included 3,911 respondents, 2,604 of whom had also been interviewed at wave 1 . Of the remainder, 148 were resident in a household surveyed at wave 1, but not interviewed until wave 2, 96 were new residents in a household surveyed at wave 1, and 1,063 were new respondents from new households. For the longitudinal sample, the household response rate was $75 \%$ and the cumulative eligible response rate $70 \% .{ }^{51}$ For the cross-sectional sample the household response rate was $53 \%$ and cumulative eligible response rate was $43 \%$. Wave 1 interviews took an average of 37 minutes, ${ }^{52}$ and wave 2 interviews an average of 35 minutes. Across both waves of the survey, the sample was broadly representative of the residential household population of England and Wales, which comprises around $98 \%$ of the total population.

The 2010 CSJPS included questions designed to explore knowledge of rights and awareness of problem resolution options in relation to hypothetical legal scenarios. Respondents were asked a series of 'Yes/No' questions about legal rights and responsibilities for one of three hypothetical scenarios, relating to housing, employment or a consumer transaction. All respondents were also asked about a relationship breakdown scenario and this has been reported on elsewhere. ${ }^{53,54}$

\footnotetext{
${ }^{49}$ P. Pleasence, N.J. Balmer, A. Patel, and C. Denvir Civil Justice in England and Wales 2009: Report of the 2006-09 English and Welsh Civil and Social Justice Survey (London: Legal Services Commission, 2010)

${ }^{50}$ H. Genn Paths to Justice: What People Do and Think About Going to Law (Oxford: Hart, 1999)

51 The individual level response rate was a very high $93 \%$.

${ }^{52}$ An initial longer form of the questionnaire (asking about more questions in detail) averaged 42 minutes $(n=762)$, with the final questionnaire averaging 35 minutes $(n=3,044)$

${ }^{53}$ Pleasence and Balmer n,6

${ }^{54}$ The use of hypothetical scenarios, or vignettes, has a number of advantages in the examination of beliefs. Watson et al. (K.D. Watson, M.J. Polonsky and M.R. Hyman 'Designing Vignette Studies in Marketing' 10 (2002) Australasian Marketing Journal, 3, 41-58.) summarised the benefits of vignette approaches to include
} 
For each of the first three hypothetical scenarios, respondents were randomised into three sub-groups, with a time-related aspect of the scenarios altered for each sub-group. The purpose of this variation was to allow for examination of the extent to which people regard legal rights and responsibilities as time-dependent. While we report on this aspect of the scenarios below, in most instances we focus on knowledge across respondents as a whole, while accounting for the experimental conditions as far as possible.

In the housing scenario, 'Alisha' (the protagonist) agrees to rent a house ${ }^{55}$ from a landlord who lets out a number of properties and lives elsewhere. Six weeks after moving in, she discovers that the bath has been leaking, causing the house to become damp. She asks the landlord to repair the leak. Without providing any notice, the landlord visits the house one afternoon and, after knocking on the door, lets himself in to inspect the leak. At this point in the scenario, respondents were asked whether the landlord is entitled to enter the house in this way and whether the landlord is legally obliged to repair the leak. Respondents were then told that the landlord refuses to repair the leak, and that, three months after moving in she herself pays for the repair to be done and deducts the cost from the next rent payment. She does not tell the landlord that she is going to do this, but encloses a note with the rent payment explaining what she has done. After the next rent becomes due, the landlord calls Alisha and says that she must leave the house in 28 days' time. The landlord says she is in breach of the tenancy agreement by not paying the rent in full. At this point in the scenario, respondents were asked whether Alisha has breached her tenancy agreement by not paying her rent in full and whether, if she refuses to leave, the landlord is able to evict her without first obtaining a Court Order. Respondents were then told that, after 28 days have passed, two employees of the landlord arrive at the house and say they have been sent by the landlord to help Alisha move out.

enhancement of respondent involvement, greater realism in the survey context, enhancement of measurement reliability and construct validity. However, the vignette approach is far from limitation free (Denvir, et al, n.6). Risks of ambiguity and misinterpretation remain. Moreover, as is the case more generally, individuals can feel compelled to respond to knowledge-based questions in a manner other than 'don't know' (R. Nadeau, R. and R.G. Niemi 'Educated Guesses: The Process of Answering Factual Knowledge Questions in Surveys' 59 (1995) The Public Opinion Quarterly, 3, 323-346.), even in the face of considerable uncertainty (D. Chong, D. 'How People Think, Reason, and Feel about Rights and Liberties' 37 (1993) American Journal Of Political Science, 3, 867899.). Responses can therefore sometimes constitute 'wild guesses'. Also, people without knowledge may sometimes answer fact-based questions in a manner no different to how they would answer attitudinal questions (R. Tourangeau and K. Rasinski 'Cognitive Processes Underlying Context Effects in Attitude Measurement' 103(1998) Psychological Bulletin, 3, 299-314.)

${ }^{55}$ In the housing scenarios, respondents were told that Alisha had a lease for six months, one year or two years. 
Respondents were asked if the two employees have the legal right to enter the property to remove Alisha's belongings. Finally, respondents were told that before the $28^{\text {th }}$ day the landlord obtained a Court Order stating that ALISHA must leave the house by the $28^{\text {th }}$ day. Respondents were then asked whether the two employees now have the legal right to enter the property to remove Alisha's belongings after 28 days have passed. ${ }^{56}$

In the employment scenario, Alisha (aged 59) has been working 48 hours per week as an employee of Zap Computers, earning $£ 5.50$ per hour. ${ }^{57}$ Her manager says he needs her to increase her hours to 50 hours per week, but Alisha does not want to work the extra hours. Her manager shows her part of her contract that says she can be asked to work up to 50 hours per week. Respondents were then asked whether Alisha has to work 50 hours per week, whether her salary is above or below the (2010) national minimum wage, and whether the minimum wage varies by age. Respondents were then told that Alisha had been asking to see the main terms of her contract since she started working at Zap Computers, and asked whether she has a legal right to see these. One month later she is told that she is going to lose her job. At this point in the scenario, respondents were asked whether Alisha is covered by the full range of (time-dependent) unfair dismissal laws. Finally, respondents were told that Zap Computer's personnel manager explains that ZAP is reducing the number of technicians it employs, and that ALISHA is going to be made redundant. The personnel manager tells her it is only fair that 'the older staff go first'. Respondents were asked whether Zap Computer's is allowed to consider Alisha's age in deciding who is to be made redundant. ${ }^{58}$

In the consumer scenario, Alisha buys a new 'off the shelf' sofa from local discount shop SOFAS4U. She agrees a delivery date that is in two weeks' time. No delivery is made on

\footnotetext{
${ }^{56}$ The 'correct' answers to the questions were that (1) the landlord cannot enter the property in the way described, (2) the landlord is legally obliged to repair the leak, (3) Alisha breaches her tenancy agreement by not paying her rent in full, (4) the landlord cannot evict Alisha without first obtaining a Court Order, (5) the two employees do not have a right to enter the property, and (6) the two employees still have no right to enter the property following the Court Order being obtained.

${ }^{57}$ In the case of the employment scenario, respondents were told that Alisha had been in her job for six months, one year or two years.

${ }^{58}$ The 'correct' answers to the questions were that (1) Alisha does not have to work for 50 hours per week, (2) Alisha's salary is below the national minimum wage, (3) the national minimum wage does vary by age, (4) Alisha does have a legal right to see the main terms of her employment contract, (5) Alisha is covered by the full range of unfair dismissal laws in the case of 1 and 2 years' employment, but not in the case of 6 months' employment (though the position is different today), and (6) Zap Computers cannot consider Alisha's age in deciding who is to be made redundant.
} 
the scheduled delivery date. When Alisha calls SOFAS4U, the shop says they forgot to send the sofa out. Respondents were asked whether Alisha has the right to cancel the order and get a refund. They were then told that the sofa is delivered the next day. However, after Alisha receives the sofa she decides she does not want it. ${ }^{59}$ She has not yet unpacked the sofa, but SOFAS4U tell her they do not accept returns or offer refunds. At this point in the scenario respondents were asked whether SOFAS4U have to take the sofa back and provide a refund, and whether the situation would be different had Alisha bought the sofa from SOFAS4U's website instead of their shop. Respondents were then told that Alisha keeps the sofa, but when she unpacks it the next day, she discovers a minor defect that SOFAS4U should be able to repair easily. She calls SOFAS4U and asks them if they will arrange for a replacement or repair. SOFAS4U say she should get in touch with the manufacturer and not them. Respondents were then asked if SOFAS4U are legally obliged to replace the sofa. Finally, respondents were told that the sofa then collapses when two of Alisha's friends sit down on it at the same time. Alisha calls SOFAS4U and the manufacturer, but finds that they have both gone bust. The sofa had cost $£ 400$ and Alisha paid with a credit card. She decides to call the credit card company to see if they will pay for the repair or give her a refund. The credit card company says her problem has nothing to do with them. Respondents were asked whether the credit card company is right that Alisha's problem is nothing to do with them. ${ }^{60}$

In total, 1005 respondents were asked questions about the housing scenario, 966 about the employment scenario and 982 about the consumer scenario.

In the next section we describe the patterns of answers provided to the scenario based legal rights questions. Then in the following section we set out the results of a series of statistical analyses undertaken to explore the drivers of knowledge as exhibited through the scenario questions.

\section{Analysis}

\footnotetext{
${ }^{59}$ In the case of the consumer scenario, respondents were told that Alisha decided to return goods after one day, three days or seven days.

${ }^{60}$ The 'correct' answers to the questions were (1) Alisha does not have the legal right to cancel the order, (2) SOFAS4U are not legally obliged to take the sofa back and provide a refund if bought from their shop, (3) SOFAS4U are legally obliged to take the sofa back and provide a refund if bought from their website, (4) SOFAS4U are not legally obliged to replace the faulty sofa, and (5) the credit card company is also responsible.
} 
First we used simple descriptive statistics to look at how respondents answered the housing, employment and consumer scenarios and the number of correct answers they gave. We then compare this to the scores they would have obtained had they relied on chance (guessing) alone. We explore which problems respondents had particular trouble or ease answering, before turning to explore what factors were associated with higher/lower scores.

We then fitted three multilevel binary logistic regression models designed to predict score on the basis of a range of predictor variables linked to legal literacy. These included: age (16 to 24 years old, 25 to 34 years old, 35 to 44 years old, 45 to 59 years old, 60 to 74 years old, 75+ years old); educational qualifications (apprenticeship/none, GCSE/Other, Post GCSE/pre degree, degree, unknown); professional status (routine manual/other, technical/semi-routine manual, other management/clerical, professional/senior management, legal professional); and whether respondents were recent migrants ${ }^{61}$ (within the past 10 years). The models also included a variable indicating whether respondents had recent personal experience of problems of the types being asked about, a variable indicating whether they had been at risk of experiencing problems of the types being asked about ${ }^{62}$ (apart from in the case of the consumer model, as no simple differentiation was possible), and a variable indicating whether they felt legal problems of the type included in the CSJPS should be resolved "within ... family or community" (rather than "by using lawyers or courts"). ${ }^{63}$ Finally, variables were included to reflect the experimental structure of the hypothetical scenarios ${ }^{64}$ and the household structure of the sample. ${ }^{65}$ The results section presents findings without the need for specialised statistical knowledge. However full statistical model outputs can be found in Table 3 in the statistical appendix.

\footnotetext{
${ }^{61}$ This recognises that recent migrants will generally have had less experience and opportunity to learn about the detail of English law.

${ }^{62}$ For the rented housing scenario, risk was taken to be present for all those living in rented accommodation. For the employment scenario, risk was taken to be present for all those currently in employment.

${ }^{63}$ This attitude variable was included as a proxy for practical interest in the form of the law.

${ }^{64}$ As detailed above, there were three time conditions included within the hypothetical scenarios (related to the length of the lease, the length of employment and the time elapsed since the sale). The hypothetical scenarios were therefore constructed as 'factorial vignettes' rather than 'constant variable value vignettes. Indeed, in the case of the employment scenario, the correct answers varied by condition. Thus, multilevel models were used to establish whether answers varied by condition.

${ }^{65}$ Since in some cases more than one household member answered the same questions, we explored whether responses tended to be similar between household members.
} 


\section{RESULTS}

\section{General knowledge and chancing answers}

Overall, respondents answered 59\% of the fact-based scenario questions correctly, though there was a statistically significant difference in the scores for the different scenarios. ${ }^{66}$ So, while housing scenario respondents answered $4.3(\mathrm{SD}=1.2)(71 \%)$ of their 6 questions correctly on average, and employment scenario respondents $4.0(\mathrm{SD}=1.3)(66 \%)$, consumer scenario respondents answered just $1.72(\mathrm{SD}=1.0)(34 \%)$ of their 5 questions correctly; ${ }^{67}$ an interesting initial finding given that consumer rights have been found to be among those that CSJPS respondents are most confident about. ${ }^{68}$

Figure 1 illustrates the distribution of correct answers to the housing, employment and consumer scenarios. As can be seen, the distributions are skewed towards a greater number of correct answers in the case of the housing and employment scenarios and, in stark contrast, towards a lesser number in the case of the consumer scenario. In the case of the housing scenario, $77 \%$ of respondents managed to answer 4 or more questions correctly, with $49 \%$ answering at least 5 correctly and $13 \%$ all 6 correctly. For the employment scenario the figures were slightly lower at $66 \%, 37 \%$ and $12 \%$.

\footnotetext{
${ }^{66} \mathrm{~F}=921.9, \mathrm{p}<0.001$, after adjusting consumer scores to be equivalent to other scores.

${ }^{67} 34.9 \%$ if answers to a $6^{\text {th }}$ question asked only of some respondents are included.

${ }^{68}$ Denvir et al., n.6
} 


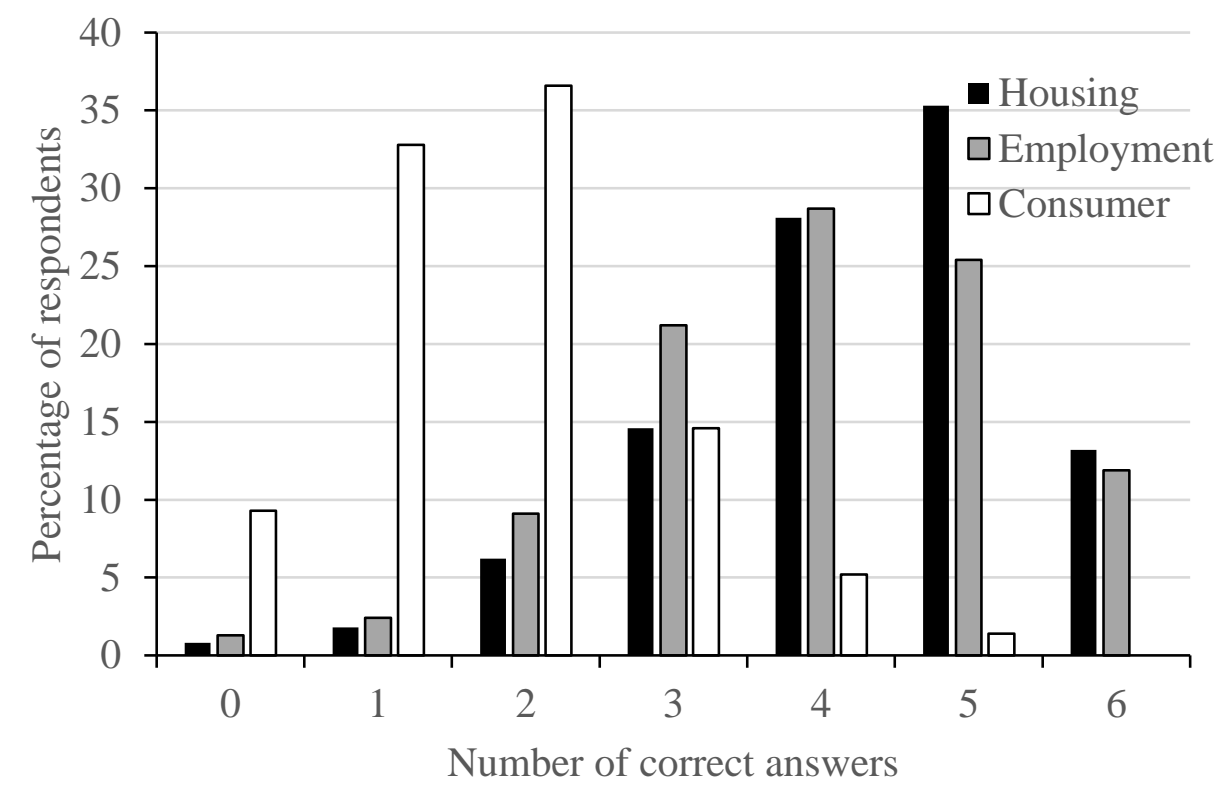

Figure 1. Number of correct answers to the six housing and employment questions and five consumer scenario questions ${ }^{69}$

Given that providing random 'Yes/No' answers to the questions could be expected to yield 4 or more correct answers $34 \%$ of the time, 5 or more correct answers $11 \%$ of the time and perfect 6 scores $1.6 \%$ of the time, the performance of respondents in respect of the housing and employment scenarios looks creditable. However, the performance in respect of the consumer scenario looks anything but. For this scenario, just $20 \%$ of respondents provided 3 out of 5 or more correct answers, $3 \%$ provided 4 or more and just $0.3 \%$ scored perfect $5 \mathrm{~s}$. This compares to the $50 \%, 19 \%$ and $3 \%$ that could be expected to be delivered by chance.

It should, though, be noted that respondents did not always offer yes or no answers to the questions; sometimes simply stating that they did not know. In fact, just 59\% of respondents answered all 6 housing questions decisively, 44\% all 6 employment questions decisively and $53 \%$ all 5 consumer questions decisively. ${ }^{70}$ Thus the above comparison with chance may be a little unfair.

\footnotetext{
${ }^{69}$ So a score of six was not possible for the consumer scenario. In total, 1,005 respondents answered rented housing, 966 employment and 982 consumer questions. For comparison, if respondents answered the questions randomly (i.e. a binomial distribution of 5 trials for consumer and six for employment/housing and a probability of 0.5 ), we would expect $3.1 \%$ scoring $0,15.6 \% 1,31.3 \% 2,31.3 \% 3,15.6 \% 4$ and $3.1 \% 5$ for consumer and $1.6 \%$ scoring $0,9.4 \% 1,23.4 \% 2,31.2 \% 3,23.4 \% 4,9.4 \% 5$ and $1.6 \% 6$ for housing or employment.

${ }^{70}$ In the rented housing scenario, 'don't know' responses varied from $6.1 \%$ to $16.5 \%$, with the highest percentage for the question exploring the landlord's ability to evict Alisha without a court order. In the employment scenario,
} 
Alternatively, a comparison between the scores of those who answered all 5 consumer questions decisively and chance sees like competing with like. However, as can be seen from Figure 2 even among only those who answered the consumer scenario questions decisively scores were substantially below those of chance! So, which questions proved so troublesome, and what were the drivers of higher scores?

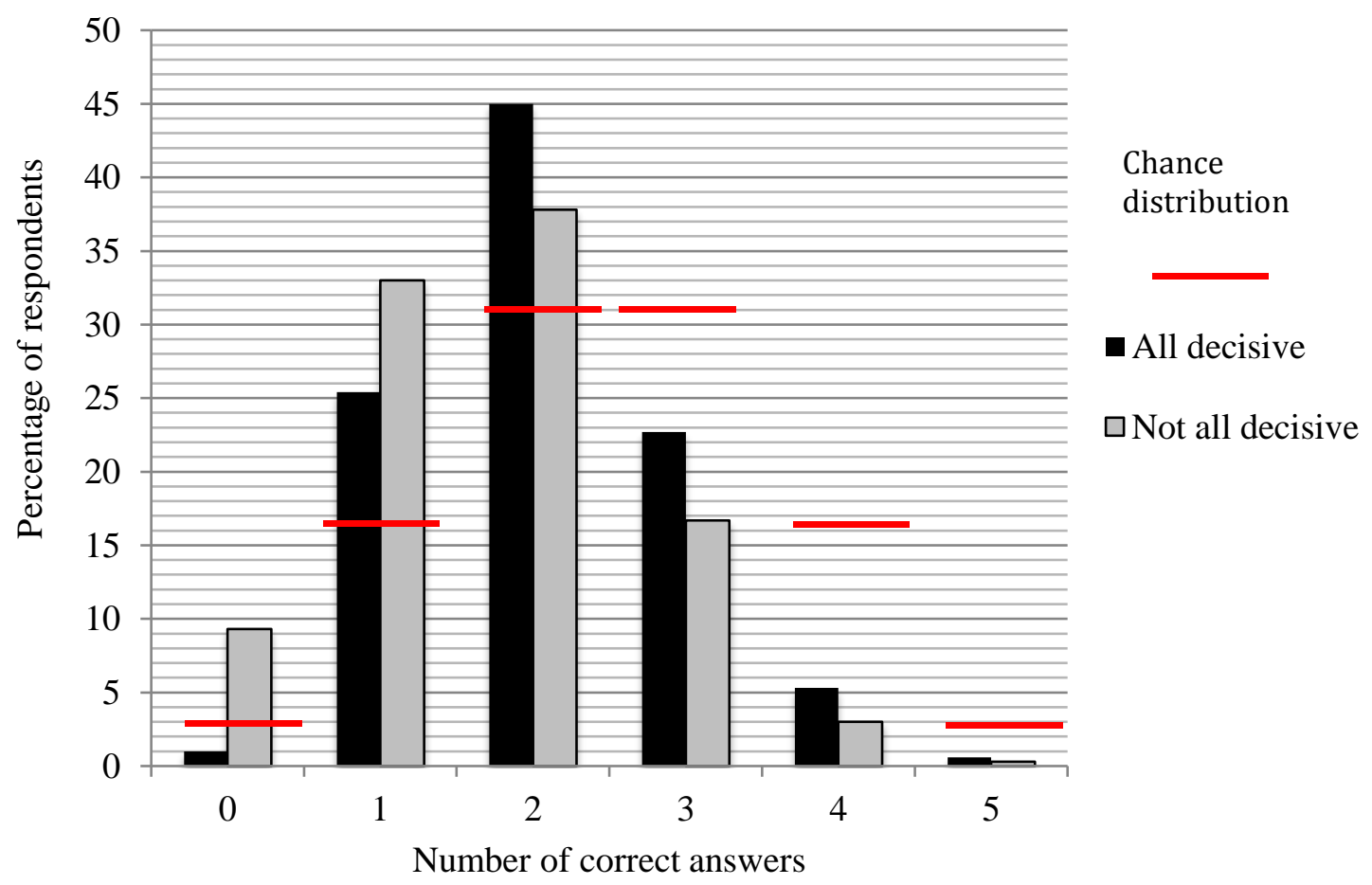

Figure 2. Number of correct answers (consumer scenario), for all answers and restricted to only those answering questions decisively, compared to what might be expected by chance

\section{Findings in detail}

Table 1 sets out the overall structure of the scenarios and respondents' success in answering each of the scenario questions. Across all scenarios/questions, respondents answered correctly

\footnotetext{
'don't know' responses varied from $2.9 \%$ to $24.0 \%$, with the highest percentage for the question regarding whether Alisha was covered by the full range of unfair dismissal laws. In the consumer scenario, 'don't know' responses varied from $11.2 \%$ to $25.4 \%$, with the highest percentage for the question asking whether the sofa company would have to provide a refund if the sofa was bought from a website. Unless decisive answers are referred to, analysis treats 'don't know' responses as being incorrect.
} 
$59 \%$ of the time. As can be seen, there was a considerable range of scores across the 18 legal rights questions asked about the scenarios. The highest score - with $95 \%$ of respondents answering correctly - was associated with the employment scenario question concerning whether an employee has a legal right to see the main terms of their employment contract. Then followed the housing scenario questions concerning whether a landlord is legally obliged to repair a leaking bath $(91 \%)$ and whether employees of a landlord are allowed to effect an eviction without a Court Order (84\%), and the employment scenario question concerning whether age can be a consideration in redundancy decisions $(82 \%)$.

The lowest scores - with just $12 \%$ and $15 \%$ of respondents answering correctly, respectively - were associated with the consumer scenario questions concerning whether a shop is legally obliged to replace a faulty item and whether an order made in a shop can automatically be cancelled for late delivery. The lowest housing scenario score was associated with the question concerning whether a landlord's employees are allowed to effect an eviction following the grant of a Court Order (33\%).

The lowest employment scenario score was associated with the question concerning when employees are covered by the full range of unfair dismissal laws. This was a question where the answer varied with the length of employment, and those respondents asked about an employment of just 6 months least often provided correct answers (23\%). Those asked about employments of 1 year and 2 years provided correct answers far more often $(61 \%$ and $73 \%$, respectively).

Table 1. Respondents' success in answering questions relating to each of the three scenarios (overall and for specific questions)

\begin{tabular}{|c|c|}
\hline Scenario & Specific question (percentage correct) \\
\hline \multirow{6}{*}{$\begin{array}{l}\text { Housing } \\
\text { scenario } \\
\text { overall }(71.0 \% \\
\text { correct) }\end{array}$} & Is the landlord entitled to enter the house? (77.4\%) \\
\hline & Is the landlord legally obliged to repair the leak? (91.4) \\
\hline & Has Alisha breached her tenancy agreement by not paying the rent in full (66.9\%) \\
\hline & Can the landlord be able to evict Alisha without a Court Order? (73.9\%) \\
\hline & Do the employees have the right to enter the property after 28 days? $(84.1 \%)$ \\
\hline & Do the employees have this right if a Court Order has been obtained? (32.5\%) \\
\hline \multirow{4}{*}{$\begin{array}{l}\text { Employment } \\
\text { scenario } \\
\text { overall ( } 66.2 \% \\
\text { correct) }\end{array}$} & Does Alisha have to work 50 hours per week? $(53.6 \%)$ \\
\hline & Is Alisha's salary above or below the national minimum wage? (56.5\%) \\
\hline & Does the national minimum wage vary by age? (57.6\%) \\
\hline & Does Alisha have the legal right to see the main terms of her contract? $(95.0 \%)$ \\
\hline
\end{tabular}




\begin{tabular}{|l|l|}
\multirow{4}{*}{\begin{tabular}{l} 
Consumer \\
scenario \\
\multirow{2}{*}{$\begin{array}{l}\text { overall (34.4\% } \\
\text { correct) }\end{array}$}
\end{tabular}} & Is Alisha covered by the full range of unfair dismissal laws? (52.4\%) \\
\cline { 2 - 2 } & Can Alisha's age be considered in deciding to make her redundant? (82.1\%) \\
\cline { 2 - 2 } & Do SOFAS4U have to take the sofa back and provide a refund? (34.2\%) \\
\cline { 2 - 2 } & Is SOFAS4 on the website, would SOFAS4U have to provide a refund? (52.9\%) \\
\cline { 2 - 2 } & Is the problem nothing to do with the credit card company (57.8\%) \\
\hline
\end{tabular}

\section{Knowledge where it is needed}

There is, of course, a big difference between knowledge deficits among those who are unlikely to require specific knowledge and those who will potentially require it. Figure 3 sets out the different housing scenario scores of those respondents living in the rented sector-and therefore more at risk of problems of the type depicted in the scenario - and those living elsewhere.

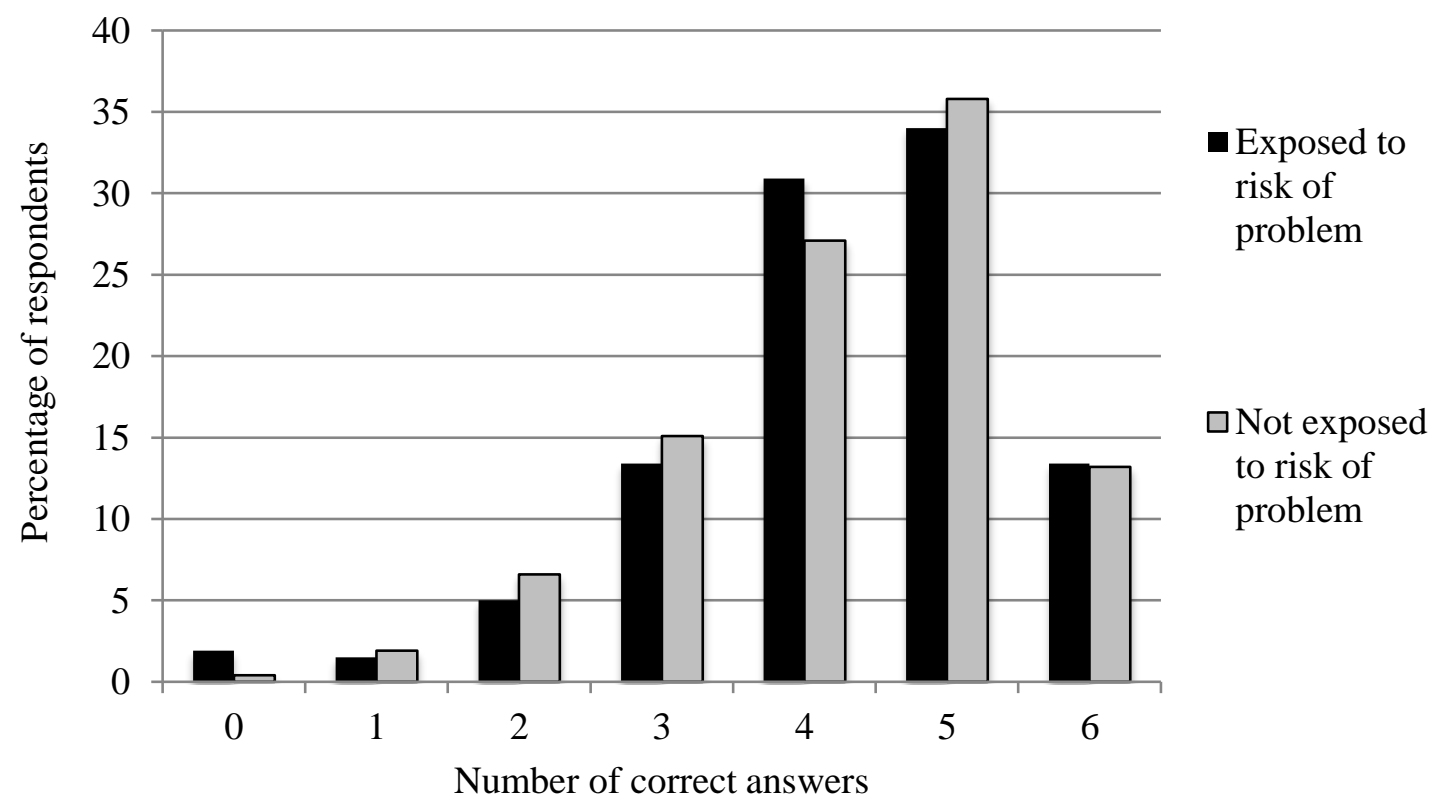

Figure 3. Number of correct answers to the housing scenario questions on the basis of whether or not respondents were living in rented housing

As can be seen, the pattern of scores looks quite similar for each of these groups. Indeed, there was no difference in the proportion of correct responses provided by respondents living in the rented sector (4.3 out of 6 ) and living elsewhere (4.3 out of 6). Looking at those who reported having actually experienced similar housing problems, they correctly answered a slightly 
higher proportion of questions (4.5 out of 6), but the difference was not significant, owing to just 21 respondents falling into this group.

Figure 4 sets out the different employment scenario scores of those respondents in employment ${ }^{71}$ - and therefore, again, more at risk of such problems - and those not in employment. As can be seen, in this instance markedly different patterns can be seen, with those in employment scoring significantly higher. On average, those in employment answered 4.3 out of 6 questions correctly, compared to just 3.6 for those not in employment, a statistically significant difference. ${ }^{72}$ However, there was no significant difference in the scores of the 26 respondents who reported having experienced similar employment problems.

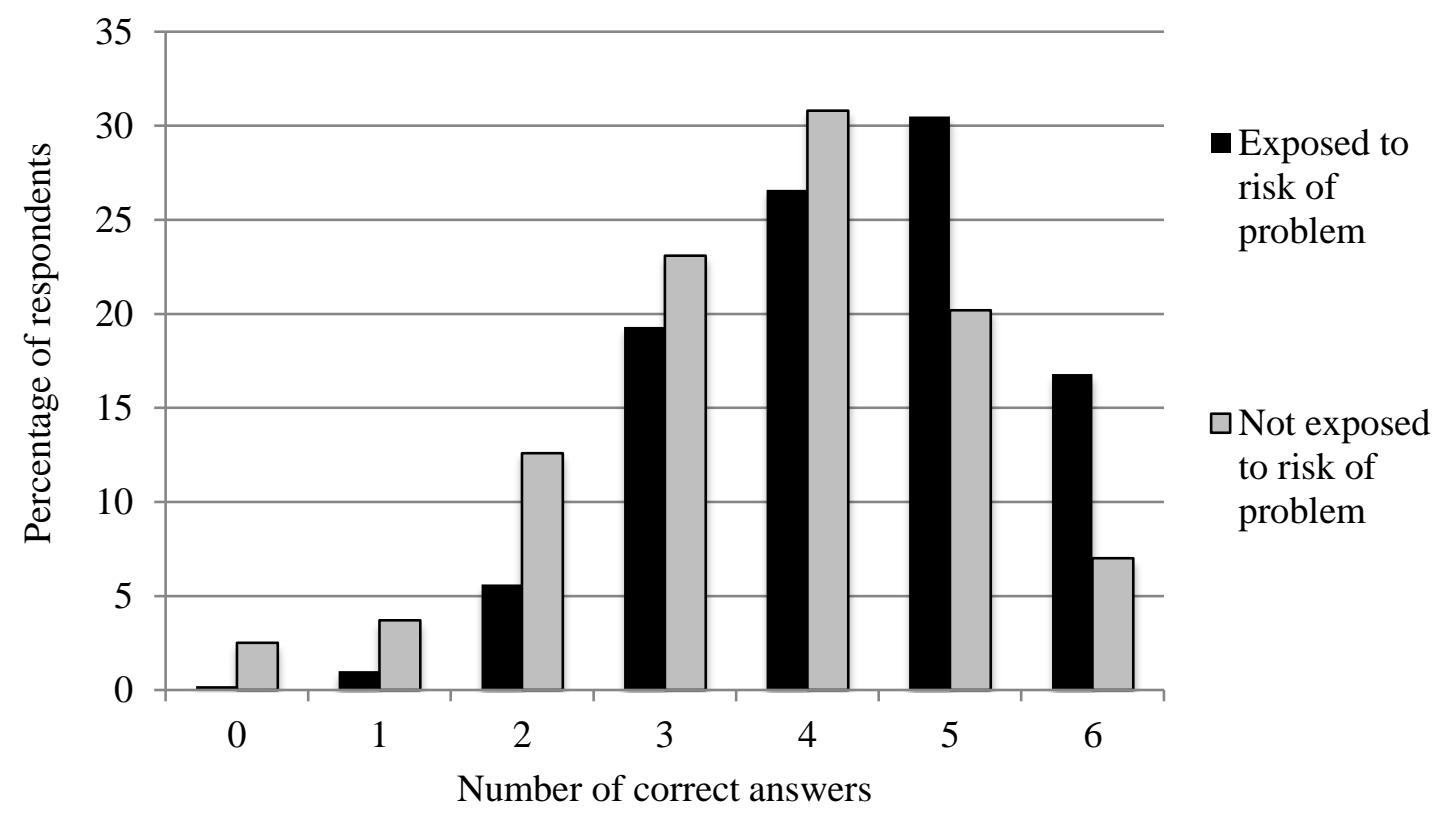

Figure 4. Number of correct answers to the employment scenario questions on the basis of whether or not respondents were in employment

For the consumer scenario, there was no means to identify respondents substantially more at risk of experiencing similar problems, but, as Figure 5 illustrates, a comparison of the scores of those who actually reported problems concerning faulty goods and those who had not, suggested no difference. Both groups answered 1.7 of the 5 questions correctly.

\footnotetext{
71 This included self-employed respondents.

$72 \mathrm{~T}=-7.88, \mathrm{p}<0.001$.
} 


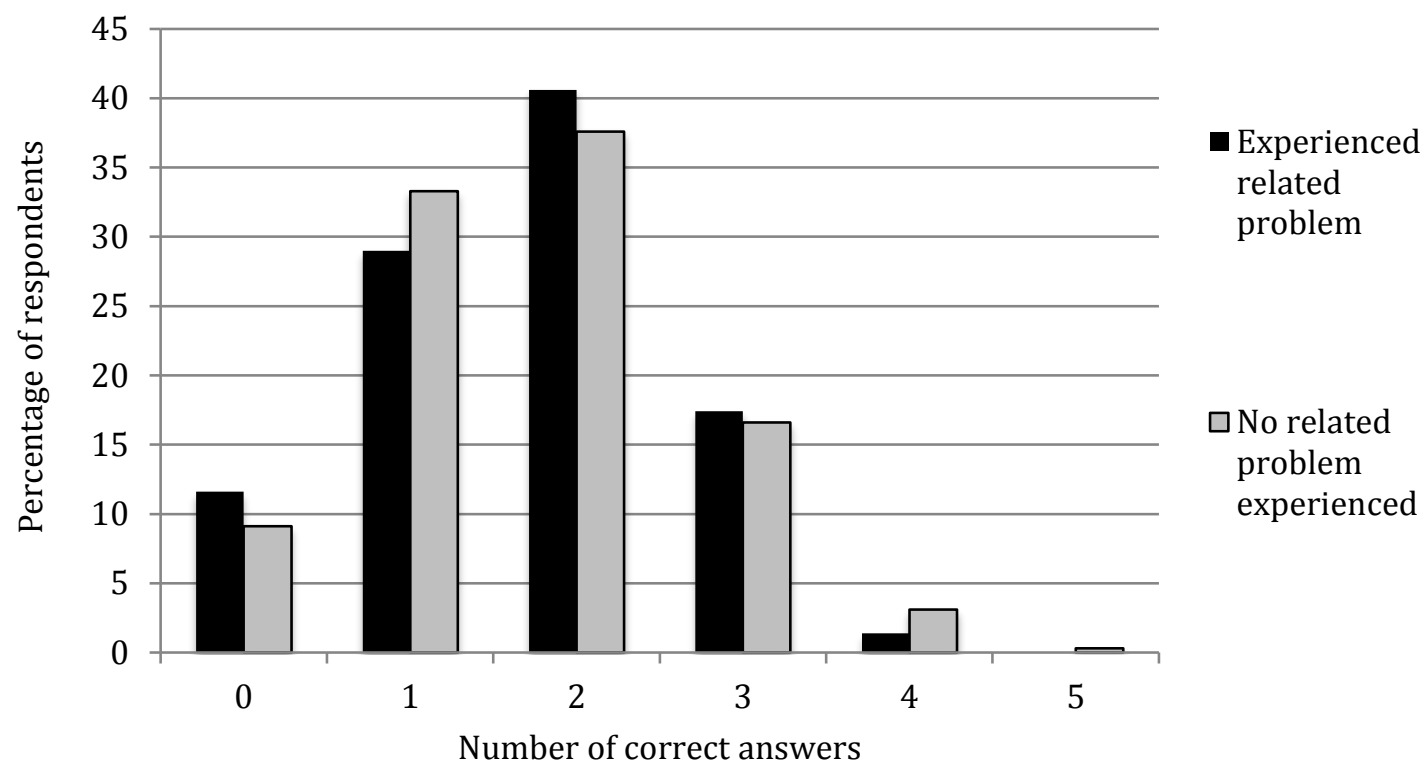

Figure 5. Number of correct answers to the consumer scenario questions on the basis of whether or not respondents reported having experienced a recent problem concerning faulty goods

\section{Factors associated with knowledge}

To identify factors associated with higher levels of knowledge of legal rights and responsibilities controlling for other matters, we employed multilevel logistic regression to predict respondents' scores in relation to each of the housing, employment and consumer scenario questions. ${ }^{73}$ Table 2 shows the factors associated with the number of questions answered correctly for each of the three scenarios.

\footnotetext{
${ }^{73}$ Model outputs set out in the statistical appendix.
} 
Table 2. Factors associated with the number of questions answered correctly for each scenario (full details of the statistical models can be found in the statistical appendix)

\begin{tabular}{lccc} 
& \multicolumn{2}{c}{ Whether Statistically Significant in Model } \\
\cline { 2 - 4 } Variable & Housing & Employment & Consumer \\
\hline Age & $\checkmark$ & $\checkmark$ & $\checkmark$ \\
Education qualifications & $\checkmark$ & & $\checkmark$ \\
Professional status & $\checkmark$ & & \\
Recent migrant & & $\checkmark$ & \\
Experience of similar problem & & & \\
Risk of similar problem & & $\checkmark$ \\
Attitude to problem resolution & $\checkmark$ & $\checkmark$ \\
Scenario structure & & $\checkmark$ & \\
Household effect & & & \\
\hline
\end{tabular}

As shown, age was found to be significantly associated with legal knowledge across all three scenarios. The oldest respondents consistently obtained relatively low scores, while middleaged respondents generally performed relatively well. However, as Figure 6 illustrates, ${ }^{74}$ there were some differences in the patterns of association between scenarios. For example, the youngest respondents scored significantly lower than those in other age groups in relation to the housing scenario, but performed relatively well in relation to the other scenarios.

Professional status was significantly associated with knowledge scores in relation to two scenarios, the housing and consumer scenarios, but not the employment scenario. In the case of both the housing and consumer scenarios, legal professionals scored higher than others $^{75}$ and, more subtly, knowledge appeared to increase with professional seniority.

Educational qualifications were found to be significantly associated with legal knowledge in the case of only one scenario, the rented housing scenario. Here, a lack of qualifications was associated with significantly higher scores. There was little evidence of

\footnotetext{
${ }^{74}$ Figure 6 is based on simulations from the models, controlling for other variables.

${ }^{75}$ Incidentally, while small numbers of legal professionals scored higher better than other respondents in housing and consumer scenarios, they were far from perfect. Only 7 of 18 answered all rented housing questions correctly, while none answered all of the employment or consumer questions correctly (of 8 and 12 respectively).
} 
qualifications, or lack thereof, relating to success in answering the employment or consumer scenario questions.

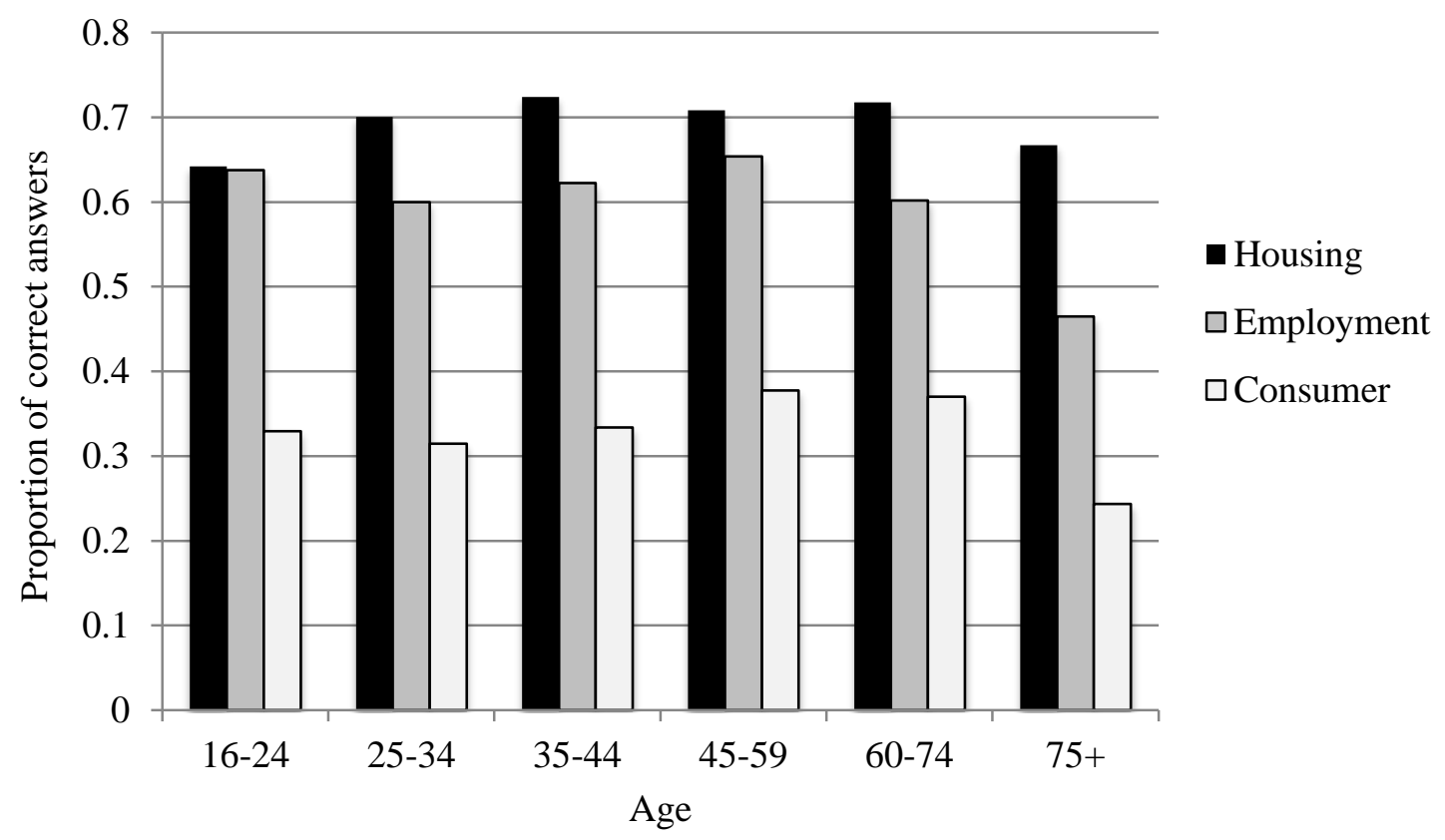

Figure 6. Association between age and legal knowledge for each of the three scenarios, derived from the statistical models and controlling for other variables

Whether respondents had migrated to the UK within the past ten years was not found to be significantly associated with legal knowledge in relation to any scenario. While this group scored lower than others across all three scenarios ${ }^{76}$ the small number of recent migrants included in the models ${ }^{77}$ was insufficient to confirm the significance of differences of the magnitude observed.

Turning to respondents' experience of problems of the types asked about, again no significant associations were found with legal knowledge, although, also again, numbers were small. $^{78}$

\footnotetext{
${ }^{76}$ On the basis of simulations from the models, controlling for other variables.

${ }^{77}$ There were just 28 recent migrants in the housing model, 36 in the employment model and 31 in the consumer model.

${ }^{78}$ There were just 21 respondents who had experienced similar problems in the housing model and 26 in the employment model. In both these cases respondents scored higher than those who had not experienced problems (on the basis of simulations from the models, controlling for other variables), but the findings were not significant.
} 
However, a significant association was found between respondents' exposure to the risk of employment problems and legal knowledge. Here, simulation from the model suggested that, controlling for other factors, those at risk of employment problems would be expected to answer $65 \%$ of questions correctly, compared to $60 \%$ for other respondents. This association was not mirrored in the case of the housing scenario.

Elsewhere, respondents who disagreed that, in general, problems should be resolved within the family or community, rather than by using lawyers or courts, were found to score significantly higher in the housing scenario than those who were neutral on the matter. ${ }^{79}$

Finally, turning to methodology related variables, the experimental elements of the hypothetical scenarios were found to be significantly associated with legal knowledge scores in the case of the employment scenario, with respondents scoring lower when presented with a scenario in which Alisha had been employed for six months, as opposed to one or two years. This reflects the fact that the correct answers were different for this condition, and a similar answer pattern to those associated with the other conditions yielded a lower score.

Also, there were significant household effects in relation to housing and employment scenario scores. This indicated that where more than one household member answered the questions, scores were likely to be related. No household effect was observed in relation to the consumer scenario.

\section{CONCLUSION}

Our findings shed important and extensive new light on the public's understanding of legal rights and responsibilities. In line with previous studies ${ }^{80}$, our results make evident a substantial public legal knowledge deficit across England and Wales. Overall, respondents answered only $59 \%$ of our fact-based scenario questions correctly; only moderately eclipsing

\footnotetext{
For the consumer model, the model suggested that, controlling for other factors, those who had experienced similar problems scored slightly lower than others.

${ }^{79}$ In percentage terms, simulated from the statistical model and controlling for other variables, those who held no strong views would be expected to answer $68 \%$ correct on average, compared to $71 \%$ for those who 'agreed' and $72 \%$ per cent for those who 'disagreed'.

${ }^{80}$ See e.g. Cortese, n.6; Williams \& Hall, n.6; Saunders, n.6; Baker \& Emery n.6;, Darley et al. n.6; Kim, n.16, Darley et al.29; Barlow et al. 2005, Militello et al. n.6, Panades et al. n.6, Parle n.6; Pleasence \& Balmer n.6; Denvir et al n.6.
} 
chance. Also in line with previous studies our results indicate that this deficit is greater in some areas of law than others. ${ }^{81}$

So, while modest levels of public understanding were evident in respect of rented housing ( $71 \%$ correct) and employment law (66\% correct), profound ignorance was observed in the case of consumer law. On average, consumer scenario respondents answered just 34\% of 5 consumer law questions correctly; a score substantially worse than would be expected by chance! Indeed, just $12 \%$ and $15 \%$, respectively, correctly answered questions concerning whether a shop is legally obliged to replace a faulty item and whether an order made in a shop can automatically be cancelled for late delivery.

Despite this profound ignorance, consumer issues represent the most common form of justiciable issue and those about which CSJPS respondents expressed greatest confidence in their legal knowledge. Indeed, 66\% of those who reported consumer problems in the 2010 and 2012 CSJPS professed to understand their rights either 'mostly' or 'completely'. However, when we compared the legal knowledge scores (as derived from hypothetical scenario questions) of those who reported consumer problems with those who did not, we found no difference. Moreover, when we compared the scores of those who claimed 'complete' understanding of their consumer rights with others, we found that they scored worse still. People think they know their consumer rights, but they do not.

So, what is going on here? Building on earlier findings concerning public understanding of family law ${ }^{82}$, which suggested that people's beliefs are influenced by social norms and personal moral viewpoints ${ }^{83}$, we here go further and suggest that the profound mismatch between people's actual and professed understanding of the law in the case of consumer law is likely strongly influenced by the practice norms of retailers. Respondents' beliefs about consumer law, while strikingly wrong, are also strikingly in line with retail practice, where cancellations of orders for late (or even on-time) delivery are routinely accepted, refunds are consistently provided for 'mistake' purchases and defective products are ordinarily replaced with new ones.

Happily, in the case of employment law, it appeared that those at risk of problems (i.e. those in employment) had greater levels of relevant legal knowledge than others (72\% versus $60 \%$ ). Though, this difference could not be seen among those who actually reported

\footnotetext{
${ }^{81}$ For previous studies, see: Saunders, n.6; Casebourne et al, n. 7; Pleasence \& Balmer n.6.

82 Pleasence \& Balmer n.6.

${ }^{83}$ see, also, Ross et al, n.30; Kim, n.16, Barlow and Lewis, n.25. Lewis, et al, n. 16)
} 
employment problems. But numbers were small and definitive conclusions not possible. In the case of rented housing law, those at risk of problems appeared not to have any knowledge advantage, although in this case there was some suggestion that those who had faced problems may have been slightly more knowledgeable. However, numbers were again small and definitive conclusions not possible.

Our findings concerning the social patterning of legal knowledge indicated that the oldest CSJPS respondents were more likely to perform poorly, while middle-aged respondents were more likely to perform relatively well in answering the hypothetical scenario questions. In the case of the housing and consumer scenarios, knowledge seemed to increase somewhat along with professional standing (with lawyers, perhaps unsurprisingly, scoring highest). There was also a slight suggestion that knowledge was related to time spent living in the UK, though numbers were too small (in the case of recent migrants) to draw conclusions.

In highlighting a substantial deficit in the public's understanding of legal rights and responsibilities - even among those for whom particular rights and responsibilities have specific bearing - the implications of our findings are profound. With law ubiquitous in everyday life, the ubiquity of ignorance of law is of evident concern.

Knowledge of legal rights and responsibilities provides a framework that informs expectations and enables the management of risk in social and economic interactions. ${ }^{84}$ It is also critical to any role law may have in guiding social behaviour and, as the Public Legal Education and Support Task Force noted, contributing to the "agendas of government". ${ }^{85}$ It is also relevant to the rule of law. Unequal knowledge of law weakens equality under law and there is, anyway, an arbitrariness to unknown law, whatever its democratic origins. ${ }^{86}$ As Lord Diplock observed in 1975:

"The acceptance of the rule of law as a constitutional principle requires that a citizen, before committing himself to any course of action, should be able to know in advance what are the legal principles which flow from it." $" 87$

\footnotetext{
${ }^{84}$ Meager, n. 16

${ }^{85}$ Public Legal Education and Support Task Force. Developing Capable Citizens: The Role of Public Legal Education (London: PLEAS Task Force, 2007) 29

${ }^{86}$ M. Galanter, 'Why the Haves Come Out Ahead: Speculations on the Limits of Legal Change' 9 (1974) Law and Society Review, 1, 95-160.

${ }^{87}$ Black-Clawson International Ltd. V. Papierwerke Waldhof-Aschaffenburg AG [1975] AC 591, 638 D.
} 
Of course, Lord Diplock here identifies that citizens of a democratic state cannot be assumed a passive role in their understanding of law. Citizens have a responsibility to inform themselves of laws relevant to their activities. However, given that citizens have only limited comprehension of the extent to which law impinges upon contemporary life ${ }^{88}$ and that, as Lord Bingham has observed, "legislative hyperactivity has become a permanent feature of our governance" - with nearly 5,000 pages of primary legislation and 11,500 pages of subordinate legislation enacted in 2006 alone ${ }^{89}$ - the responsibility of citizens to inform themselves about the law must be quite limited. ${ }^{90}$

Thus, while the legal illiteracy of the public may not be something that threatens the fabric of democracy, it does nonetheless pose important questions about the role of law and responsibility of government to enable citizens to understand and engage with it.

Moreover, our findings of social patterning in levels of legal literacy indicate that supplementary assistance is important for some sections of the community if understanding of law is not to act as a substantial barrier to engagement with it.

The above all suggests that state powers should be mindful of public understanding of the law, and take reasonable steps to support it. Plainly, these steps extend to the national curriculum (which addresses foundational aspects of our constitutional framework and legal system within the citizenships programmes of study) and broader public legal education (PLE) efforts concerning the current state of the law. ${ }^{91}$ But there is also a particular need for PLE initiatives in the context of legislative change. After all, what government would want to enact legislation that is not known about by those to whom it applies? And in the case of new law, the challenge of supporting legal literacy is made greater by the likelihood that beliefs about law are likely to be "resistant to change". ${ }^{92}$

\footnotetext{
${ }^{88}$ P. Pleasence, N.J. Balmer and S. Reimers, 'Horses for Courses? People's Characterisation of Justiciable Problems and the use of Lawyers' in Legal Services Board (ed.), The Future of Legal Services: Emerging Thinking (London: Legal Services Board, 2010); P. Pleasence, N.J. Balmer, and S. Reimers 'What really drives advice seeking behaviour? Looking Beyond the Subject of Legal Disputes' 1 (2011) Oñati Socio-Legal Series, 6.

${ }^{89}$ And this ignores law emanating from the European Union and elsewhere.

${ }^{90}$ T. Bingham The Rule of Law (London: Allen Lane, 2010)

${ }^{91}$ These are generally quite narrowly focused. See, for example, the Living Together campaign in relation to cohabitation law (A. Barlow, C. Burgoyne, E. Clery, \& J. Smithson 'In Practice: The Living Together Campaign - The Impact on Cohabitants' (2007) Family Law, 166-169.) and the recommendations of the Vulnerable Worker Enforcement Forum (Department for Business, Enterprise and Regulatory Reform. Vulnerable Worker Enforcement Forum: Final Report and Government Conclusions London: BERR, 2008).

${ }^{92} \mathrm{Kim}$, n. 16
} 
The importance of PLE has also been heightened by the substantial cuts to legal aid brought about through the LASPO Act 2012; which have impacted not just on help provided to those engaged in formal process, but also to basic help provided to those looking to understanding the the nature of problems they face and their resolution options. As was recognised in the Public Bill Committee debates regarding the passage of the LASPO Bill, there is now a far greater public reliance on self-help in the resolution of legal disputes, including representation before courts and tribunals (Public Bill Committee 2011). Yet, while the government earmarked a " $£ 2 \mathrm{~m}$ package of support aimed at avoiding expensive and confrontational courtroom battles," to include additional funding of the legal and advice sectors to "increase legal and practical support for litigants in person in civil and family courts," has "imposed upon itself no duty to promote knowledge of rights, develop just-in-time legal information, share the third sector's burden of equipping citizens to better handle their problems alone or for that matter, inform itself as to the need for public legal education interventions". ${ }^{94}$ Thus, we can perhaps expect fewer disputes to progress to formal legal process or resolve "in the shadow of the law". ${ }^{95}$ In the case of those disputes that come before legal institutions with parties ignorant of the law, we might expect less effective argument and greater burden on the institutions concerned. ${ }^{96}$

Finally, in relation to our findings concerning consumer law, it might be thought that people's systematic lack of understanding is unproblematic in practice, as it evidences norms of behaviour (e.g. 'goodwill' returns policies) that offer greater protection than the law requires. However, over-optimism in relation to legal protection can lead people to take on far greater risk than they would want, or be able, to deal with. And it is not just consumer law that people err on to their own advantage. Our findings also highlighted that $32 \%$ of CSJPS respondents believed a tenant has the legal right to deduct from rent payments the cost of services a landlord is obliged to, but does not, provide. And similar erroneous optimism has also been documented in other areas, such as family law and employment law. ${ }^{97}$

Over-optimism as regards some aspects of the law is also mirrored by pessimism as regards others; as in the case of the $46 \%$ of CSJPS respondents who were unaware of their right

\footnotetext{
${ }^{93}$ Ministry of Justice press release, More Support for Separating Couples and Parents, 23 October 2014.

${ }^{94}$ Denvir et al, n.6: 156

${ }^{95}$ R.H. Mnookin, and L. Kornhauser 'Bargaining in the Shadow of the Law: The Case of Divorce' 88 (1979)

The Yale Law Journal, 5, 950-997.

96 Williams, n. 14, Pleasence and Balmer, n. 9.

${ }^{97}$ Pleasence and Balmer, n.14, Kim, n.16.
} 
to limit their working hours to 48 per week. Here, again, the impact of people's reliance on their understanding of the law can be highly detrimental and long lasting.

In conclusion, public ignorance of law is ubiquitous, can act to undermine efforts to navigate the legal framework of everyday life, impacts on the outcome of legal issues and imposes burdens on legal institutions. It strikes at law's efficacy, efficiency and legitimacy. It is therefore not a matter of simple academic concern, but one of practical and constitutional significance - and our findings suggest there is much that needs to be done to address it. 


\section{STATISTICAL APPENDIX}

The three statistical models fitted in relation to the hypothetical scenarios were logistic regression models (for proportions), implemented using MLwiN statistical software (Rasbash et al 2009). Logistic regression is a common model type where the response variable (e.g. respondent's score out of six in the rented housing scenario) is a proportion (i.e. $r$ correct out of $n$ questions). A multilevel model was used (with two levels) since the data was hierarchical, with scores nested within households. Multilevel models can be used to correctly account for this type of data structure.

The model is used to assess whether particular factors (e.g. age group) are associated with an increase or decrease in score. How to interpret logistic regression is set out in a range of statistical texts, though all of the key findings are summarised in simple terms in the text above, without statistical output or jargon.

Model output is set out in Table 3 below. 
Table 3. Multi-level logistic regression models predicting score on the hypothetical scenarios on the basis of a range of characteristics.

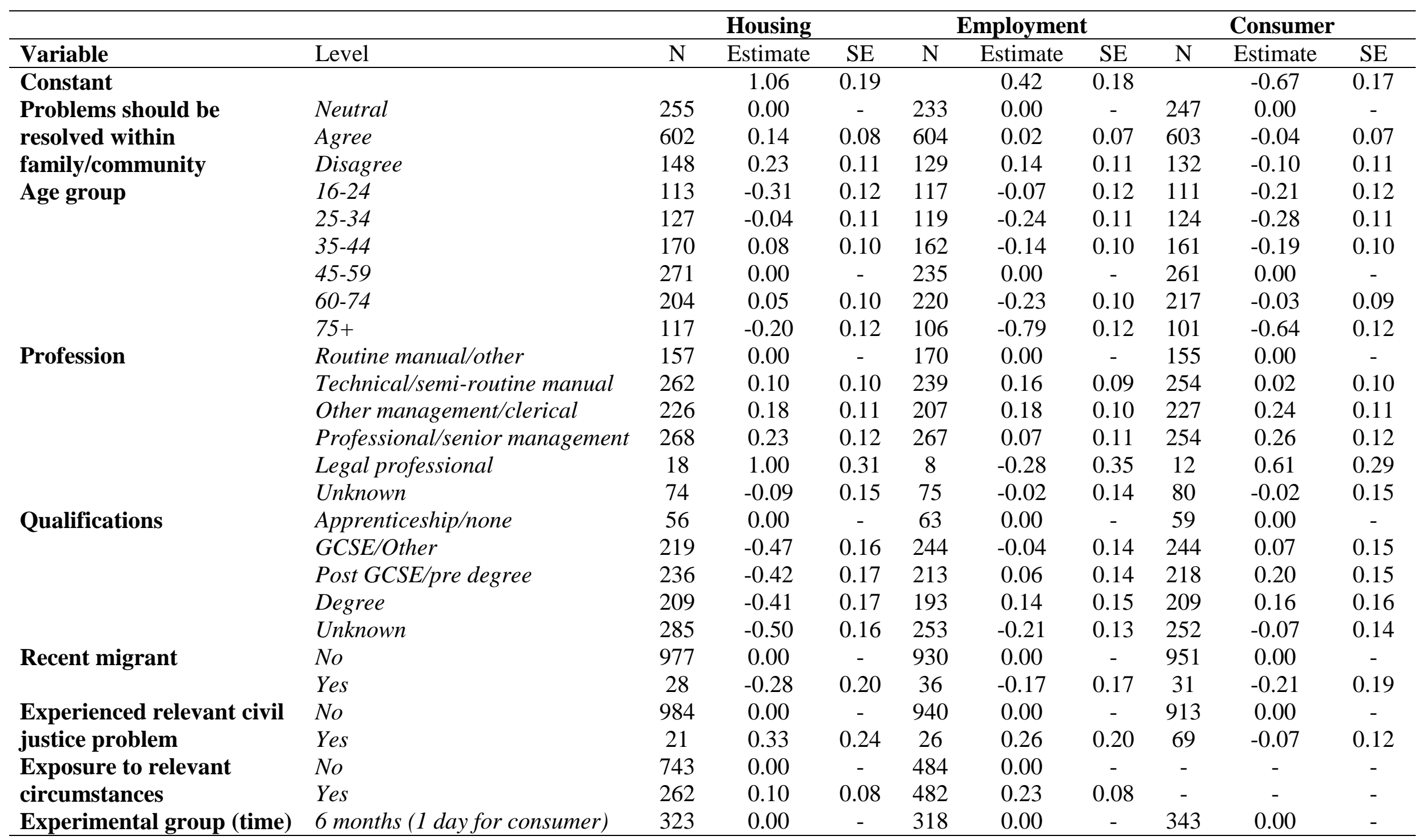




\begin{tabular}{|c|c|c|c|c|c|c|c|c|c|c|}
\hline & 1 year (3 days for consumer) & 358 & 0.13 & 0.08 & 332 & 0.41 & 0.07 & 310 & 0.01 & 0.07 \\
\hline & 2 years ( 7 days for consumer) & 324 & 0.08 & 0.08 & 316 & 0.44 & 0.07 & 329 & 0.02 & 0.07 \\
\hline
\end{tabular}

